\title{
Elk, Mule Deer, and Cattle Habitats in Central Arizona
}

\author{
MARK C. WALLACE AND PAUL R. KRAUSMAN
}

\section{Abstract}

Elk (Cervus elaphus) and mule deer (Odocolleus hemionus) distribution and use of habitats shared with cattle (Bos spp.) on a ponderosa pine (Pinus ponderosa)-bunchgrass range in central Arizona was examined. Cattle were removed from the range in 1961 and reintroduced in 1980 . A $48-\mathrm{km}$ survey route was driven through pastures containing cattle and through pastures without cattle to document the efiects cattle had on native ungulates during the summers of 1981 and 1982 . Location and number of elk, mule deer, and cattle observed along the route were recorded. Locations where animals were seen were used as sample sites to measure habitat variables: forest overstory, plant species composition, elevation, slope, exposure, and distance to water, fencing, meadow, cover, and draws. Distribution of elk and mule deer and habitats used by elk changed when cattle were introduced to the range. Significantly $(P<0.05)$ fewer elk and mule deer were seen on pastures grazed by cattle than on pastures not grazed by cattle. Use of habitats by elk shifted from open mesic and silviculturally disturbed areas to more closed forest after cattle were introduced. Use of habitats by deer was not altered when cattle were introduced to the range.

Key Words: habitat selection, discrimination function, ponderosa pine-bunchgrass

Cattle (Bos spp.) may alter elk (Cervus elaphus) and mule deer (Odocoileus hemionus) use of rangelands (Julander and Jeffery 1964, Mackie 1970, Nelson 1982 and Urness 1982). Elk use may decrease in response to cattle grazing (Skovlin et al. 1968) or be unaffected (Long and Irwin 1982). Cattle grazing can even improve elk range (Andersen and Scherzinger 1975). Urness (1982) and Longhurst et al. (1982) argued that livestock grazing pressures have created much more of our western deer habitat and that livestock can be used as a deer management tool. More empirical evidence is needed on the response of elk and deer to grazing by cattle.

In 1979 the U.S. Forest Service established the Circle-Bar pasture in the Chevelon Wildlife Management Area, Apache-Sitgreaves National Forest, Arizona. This area had not been grazed by livestock since 1961 (Adams et al. 1979. Chevelon Canyon allotment analysis. U.S. Forest Serv., Apache-Sitgreaves Natl. Forest, Ariz., mimeo). The development of the Circle-Bar pasture provided a unique opportunity to describe elk and mule deer distributions and habitat use in response to cattle on a central Arizona summer range.

\section{Study Area}

The $135-\mathrm{km}^{2}$ study area was characterized by broad, flat plateaus cut by steep, north-draining canyons. Elevations ranged from 2,135-2,500 m. Mean minimum and maximum temperatures during July-August of 1981 and 1982 were $9^{\circ} \mathrm{C}$ and $26.5^{\circ} \mathrm{C}$, respectively. Average annual precipitation in 1981 and 1982 was 46 and $64 \mathrm{~cm}$ from the lower to higher elevations, respectively, and similar to a 15-year average (1965-1980) throughout the area (Adams et al. 1979. Chevelon Canyon allotment analysis. U.S. Forest Serv., Apache-Sitgreaves Natl. Forest, Ariz., mimeo).

Ponderosa pine (Pinus ponderosa) was the dominant overstory

\footnotetext{
Authors are graduate research assistant and associate professor of wildlife ecology, School of Renewable Natural Resources, University of Arizona, Tucson 85721.

Research was funded by the Agricultural Experiment Station, University of Arizona, the USDA Forest Service, and the Arizona Game and Fish Department. Authors thank Drs. W. Shaw, M. Zwolinski, and J. Rodiek for their comments on earlier drafts of this manuscript, and B. Leopold for assistance in statistical analysis.

Manuscript accepted 24 July 1986.
}

species. Douglas-fir (Pseudotsuga menziesii), limber pine (Pinus flexilis), and white fir (Abies concolor) occurred in the canyons and higher elevations. The understory throughout the study area was dominated by Arizona fescue (Festuca arizonica), muhly grass (Muhlenbergia spp.), June grass (Koeleria cristata), and bottlebrush squirreltail (Sitanion hystrix). Small open meadows dominated by bluegrass (Poa spp.) were scattered throughout the area. Fires and silvicultural disturbances created a patchwork of seral stages. The 1956 Dudley burn ( $70 \mathrm{ha}$ ) was a midsuccessional stand with 3 to 5-m-tall ponderosa pine regeneration and a bunchgrassbuckbrush (Ceanothus fendleri) understory during the study period and 1981 and 1982. The 1975 Cliff ( $20 \mathrm{ha}$ ) and 1978 Breed ( $10 \mathrm{ha}$ ) burns were in early successional bunchgrass associations.

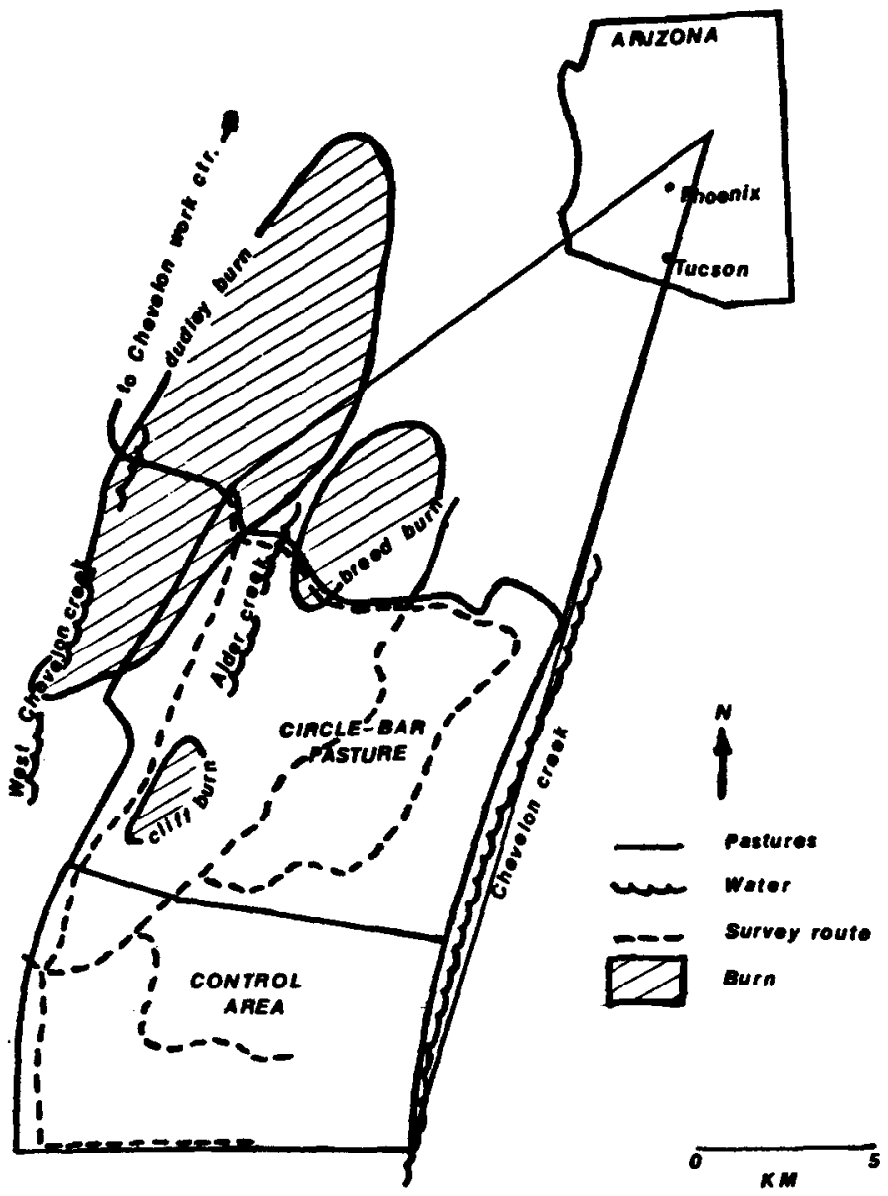

Fig. 1. Location of the Circle-Bar and control pastures in the ApacheSitgreaves National Forest, Arizona.

The study area was divided into 2 pastures: the Control and Circle-Bat pastures (Fig. 1), which were not used by livestock from 1961-1979. In 1980, 400 cows grazed on Circle-Bar.

\section{Materials and Methods}

We conducted this study in July-August 1981, and from May-October 1982. Cattle were excluded from both pastures in 1981. In 1982, cattle were excluded from the Control pasture all year but 1,000 yearling steers grazed Circle-Bar pasture from 15 May-30 July. Stray cattle were still on this pasture until October 
1982. For our analysis only data from July and August in 1981 and 1982 are compared. Grazing treatments for this study were as follows: Control ungrazed 1981, Circle-Bar ungrazed 1981, Control ungrazed 1982, and Circle-Bar grazed 1982. Cattle use on the grazed treatment was 1,750 AUM's or approximately $2.96 \mathrm{ha} / \mathrm{AUM}$.

A 48-km survey route (Fig. 1) (26 km in Circle-Bar and $22 \mathrm{~km}$ in the Control pasture) was driven $30 \mathrm{kph}$ during the morning and evening hours (0500-0900 and 1600-2000, respectively), 20 times in 1981 and 14 times in 1982. Location and number of elk, mule deer, and cattle observed along the route were recorded. We tested (Mann-Whitney U test [Conover 1980]) for differences between the grazing treatments in numbers of animals seen per kilometer driven and for animal group sizes.

Locations where animals were seen were used as sample sites to measure habitat variables. At each site the elevation, slope, exposure, and distance to water, fencing, meadow, cover, and draws was noted using onsite measurement, aerial photographs, and topographic maps. Hiding cover was defined as vegetation or topography capable of hiding $90 \%$ of a standing animal from the view of an observer.

Forest overstory at each site was described with a spherical densiometer to estimate canopy coverage (Strickler 1959) and a 10-factor wedge prism to estimate basal area. A 25-m line-intercept transect (Strong 1966) established in a random direction from each site where animals were observed was used to estimate percentage of total frequency, density, and coverage of understory plant species. A dominant species for trees, shrubs, grasses, and forbs was determined by ocular estimation at each site. These estimates were used as dominant species descriptors for the site.

Nominal scale data were tested with G-factor analysis (Sokol and Rohlf 1969:735-738) using $\alpha=0.10$. Ratio scale data were examined using discriminant analysis to descriptively explore habitat use by the ungulates (after Ferrar and Walker 1974 and Hudson 1976). Measures of plant species which occurred on less than $5 \%$ of the transects were excluded from the analyses. A step-wise (5-step limit) selection procedure was used in the discriminant analyses to determine important variables for differentiating ungulate sites. Variables were selected by the criteria of maximizing Mahalanobis distance. The original data were then reclassified using the derived discriminant function scores to evaluate the effectiveness of the discriminating variables. Analyses were conducted using the Statistical Package for the Social Sciences (Klecka 1975).

\section{Results and Discussion}

There was no difference in number of elk seen between years on the Control pasture, and elk numbers did not differ betwen the Control and Circle-Bar pastures in 1981. Significantly fewer $(P<0.05)$ elk were seen, however, on the Circle-Bar pasture in 1982 than in 1981 (Table 1). Also, fewer elk were seen on the Circle-Bar

Table 1. Median numbers of elk and mule deer seen per kilometer driven on the Control and Circle-Bar pastures during July and August of 1981 and 1982. Cattle graxing occurred only on the Circle-Bar pasture in 1982.

\begin{tabular}{lccccc}
\hline \hline & \multicolumn{2}{c}{1981} & & \multicolumn{2}{c}{1982} \\
\cline { 2 - 3 } \cline { 5 - 6 } & Control & Circle-Bar & & Control & Circle-Bar \\
\hline$N^{*}$ & 20 & 20 & & 13 & 14 \\
Elk & $0.21^{\mathrm{b}}$ & $0.13^{\mathrm{b}}$ & & $0.50^{\mathrm{b}}$ & 0.01 \\
Mule deer & $0.02^{\mathrm{bc}}$ & $0.07^{\mathrm{bc}}$ & & 0.02 & 0.00 \\
\hline
\end{tabular}

Number of survey routes driven

bignificantly different $(P<0.05)$ from the Circle-Bar pasture in 1982

'Significantly different $(P<0.05)$ between 1981 Circle-Bar and Control pastures.

pasture than the Control Pasture in 1982. Skovlin et al. (1968), Mackie (1970), and Knowles and Campbell (1982) also indicated that elk use descreased in pastures where cattle grazed.

Observations of elk on the Circle-Bar pasture decreased with the introduction of cattle in $1982(X=0.75$ elk $/ \mathrm{km}$ the week prior to 15 May compared with $0.12 \mathrm{elk} / \mathrm{km}$ the week after 15 May). Elk observations on the grazed pasture did not again exceed $0.12 / \mathrm{km}$ until after 7 September. Nelson and Burnell (1976) indicated a negative interaction with elk being displaced because they are subordinate to and socially intolerant of cattle. Elk seen on the Circle-Bar pasture during the cattle-grazing period, however, were frequently within $15 \mathrm{~m}$ of cattle, and interactions observed at salt blocks suggested species dominance was related primarily to number of conspecifics present. Ward et al. (1973), Knowles and Campbell (1982), and Long and Irwin (1982) also found elk and cattle to be socially compatible and observed them feeding in close proximity to each other.

Mule deer were more abundant on the Circle-Bar pasture than on the Control pasture when they were both ungrazed by cattle in 1981 (Table 1). In 1982, however, the number of mule deer on the Circle-Bar pasture decreased and was no longer significantly different from that seen on the Control pasture. Mclntosh and

Table 2. Standardized canonical discriminant coefficients for functions diseriminating elk and mule deer habitat use along survey routes in Control and Circle-Bar pastures during July and August, 1981 and 1982. Cattle grazing occurred only on the Circle-Bar pasture in 1982.

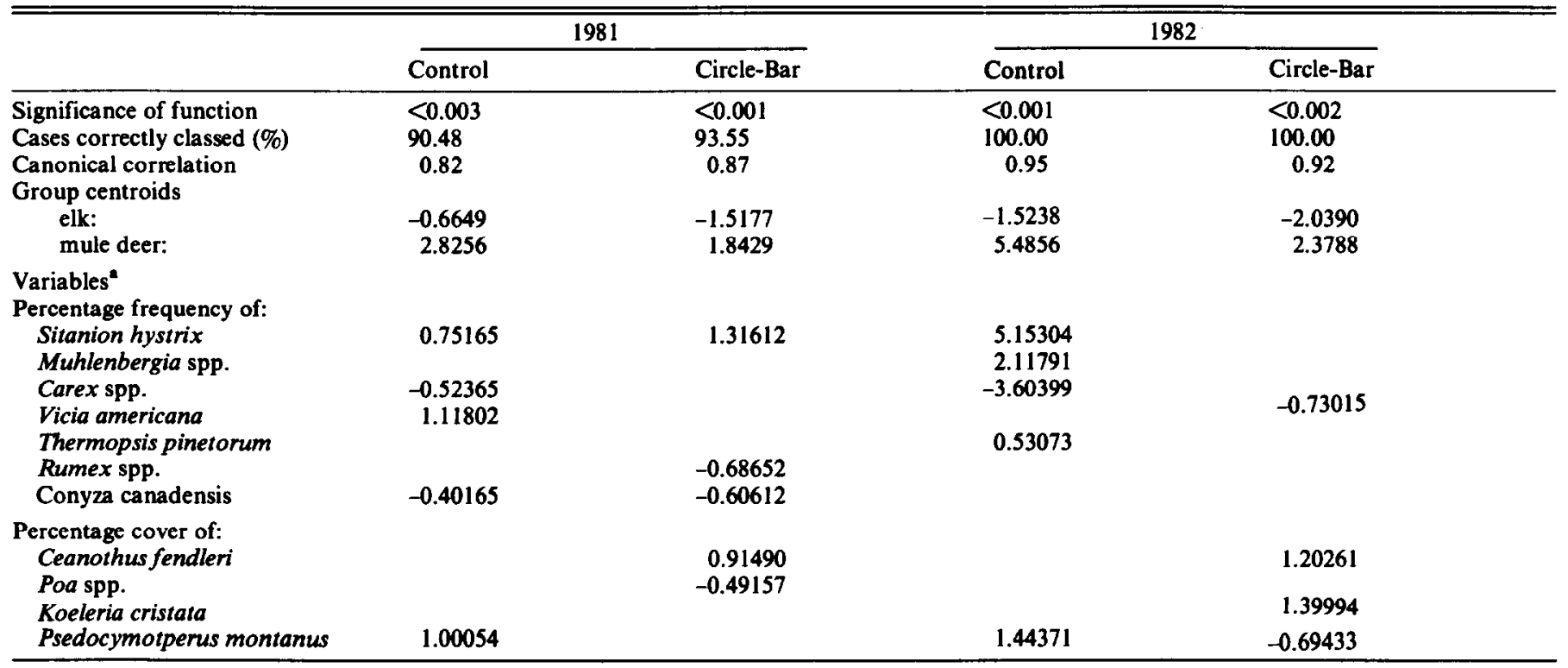

\footnotetext{
"Values are reported only for significant variables $(P<0.01)$
} 
Krausman (1982) also reported this decrease in mule deer occurrance on the Circle-Bar pasture when it was grazed by cattle.

Although fewer mule deer were seen, their distribution did not change dramatically in relation to cattle presence on the Circle-Bar pasture. Deer numbers decreased slowly but deer were consistently seen foraging and drinking with cattle. Hungerford (1970) and Ward et al.(1973) also found mule deer and cattle feeding in close proximity. Knowles (1975) reported that mule deer either moved from the area or used all parts of their home ranges more frequently when cattle were present.

We measured habitat variables on 114 sites where animals were observed during July and August: 29 and 25 elk sites in 1981 and 1982, respectively; 18 and 11 mule deer sites in 1981 and 1982, respectively; and 31 cattle sites in 1982 . Elevation, slope, and exposure were major distinguishing components of habitat use in studies by Julander and Jeffery (1964) and Sivinski (1979), but discriminant analysis indicated they were not important for differentiating ungulate habitats on the relatively flat Apache-Sitgreaves National Forest. Selective cutting, pulp wood harvest, and commercial thinning had not created the large openings or dense regrowth common in other forest types or management schemes either. Exceptions were the burns in open (early) or dense (midsuccessional) stages and the open meadows. Of the nonvegetative habitat variables measured for each species, none differed significantly between pastures or years.

Dominant species descriptors for elk sites differed between pastures and years. Elk sites on the Circle-Bar pasture during 1982 were dominated by ponderosa pine, buckbrush, and muhly, whereas, sites on the Control pasture in 1982 and both pastures in 1981 were dominated by Gambel oak, aspen (Populus tremuloides), and mesic grasses. Dominant species for mule deer sites were not significantly different between pastures or years.

Discriminant analyses of understory species of elk and mule deer sites for each pasture and year identified habitat gradients that separated elk sites (negative values) from mule deer sites (positive values) (Table 2). The understory species useful for discriminating elk from mule deer sites were representative of vegetative communities that occurred under different forest canopy or moisture classes. Discriminant function variables which discriminated elk and mule deer sites on all 3 ungrazed pastures represent a similar gradient from open mesic meadow to closed forest with shrub understory.

Observations of elk (open mesic or disturbed sites) were characterized by sedge and bluegrass or early seral weeds (sheep sorrel [Rumex spp.] and horsewood [Conyza canadensis]). Reynolds (1966) indicated elk used openings more than forested areas and Clary and Larson (1971) found elk use consistently showed an inverse relationship to ponderosa pine basal area. DelGuidice and Rodiek (1982) emphasized the importance of mesic forest openings as summer foraging sites for elk. Observations of mule deer (closed forest with shrub understory) were characterized by shade tolerant grasses and forbs. Reynolds (1966) indicated use by mule deer under ponderosa pine was nearly equal to use of openings, and deer preferred small openings to large ones. Skovlin et al. (1968) reported mule deer used forest more than openings, while Carpenter and Wallmo (1981) emphasized that mule deer use of openings was dependent upon the proximity of cover.

Elk habitats on the Circle-Bar pasture in 1982 differed from those described for the ungrazed pastures. Variables identifying elk sites were shade tolerant forbs (vetch [Vicia americana] and anice plants [Pseudocymopterus montanus]) that are commonly found under dense ponderosa pine sites. Mule deer sites were still identified by buckbrush and June grass representative of forested areas and shrub understory.

The addition of cattle as a third group enabled us to use 2 discriminant functions in the analysis of the Circle-Bar pasture in 1982 (Table 3). Vetch characterized elk sites which were discriminated from the mule deer sites associated with buckbrush, and
Table 3. Standardized canonical discriminant coefficients for discriminating elk, mule deer, and cattle habitat use along survey routes in the Circle-Bar pasture during July and August of 1982.

\begin{tabular}{lcc}
\hline \hline & \multicolumn{2}{c}{ Discriminant function } \\
\cline { 2 - 3 } & 1 & 2 \\
\hline Significance of function & $<0.002$ & $<0.002$ \\
Variance acounted for (\%) & 61.15 & 38.85 \\
Canonical correlation & 0.42 & 0.28 \\
Group centroids & & \\
$\quad$ elk: & 0.95781 & 0.902721 \\
$\quad$ mule deer: & 1.19381 & -1.668953 \\
cattle: & -1.07083 & 0.132430 \\
Variables & & \\
Percentage frequency of: & & \\
$\quad$ Muhlenbergia spp. & -1.27124 & 0.81276 \\
$\quad$ Vicia americana & 1.11319 & 1.02026 \\
Percentage cover of: & & \\
Ceanothus fendleri & 0.69862 & -1.23921 \\
Conyza canadensis & -0.92840 & -0.73240 \\
Poa spp. & -1.03976 & -0.70033 \\
\hline
\end{tabular}

"Values are reported only for significant values $(P \leq 0.01)$

cattle sites with bluegrass, muhly, and horseweed.

Cattle were much more numerous than elk or mule deer on the Circle-Bar pasture and were observed in most of the available habitats. Cattle use in the meadows, draws, and more open forested sites appeared to displace elk from these habitats, characterized by low basal areas of trees and high canopy coverage of bluegrass or muhly and seral weeds. The presence of cattle did not appear to affect patterns of habitat use by mule deer. Deer remained in forested sites that were dominated by buckbrush.

Skovlin et al. (1968) indicated that elk tolerated light stocking levels of cattle but were inhibited by moderate to heavy stocking. In our study area, a moderate level of cattle stocking affected elk and mule deer distribution and was associated with changes in habitat use by elk. The nutritional consequences of such behavioral responses by elk and mule deer are unknown but are necessary to evaluate the degree and role of competition in interactions with livestock.

\section{Literature Cited}

Anderson, E.W., and R.J. Scherzinger. 1975. Improving quality of winter forage for elk by cattle grazing. J. Range Manage. 28:120-125.

Carpenter, L.H., and O.C. Wallmo. 1981. Habitat evaluation and management. p. 399-422. In: O.C. Wallmo (ed), Mule and black-tailed deer of North America. Univ. of Nebraska Press, Lincoln.

Clary, W.P., and F.R. Larson. 1971. Elk and deer use are related to food sources in Arizona ponderosa pine. U.S. Forest Service Res. Note RM202. Rocky Mountain Forest and Range Experiment Station, Fort Collins, Colo.

Conover, W.J.1980. Practical nonparametric statistics. 2nd ed. John Wiley and Sons, Inc. New York.

DelGuidice, G.D., and J.C. Rodiek. 1982. A habitat analysis of springsummer elk range on the Apache-Sitgreaves National Forest, Arizona. p. 69-99. In: T. Britt and D. Theobald (eds), Proc. of the West. States Elk Workshop, Flagstaff, Ariz.

Ferrar, A.A., and B.H. Walker. 1974. An analysis of herbivore/habitat relationships in Kyle National Park, Rhodesia. J.S. Afr. Wildl. Manage. Ass. 4:137-147.

Hudson, R.J. 1976. Resource division within a community of large herbivores. Nat. Can. 103:153-167.

Hungerford, C.R. 1970. Response of Kaibab mule deer to management of summer range. J. Wildl. Manage. 34:852-862.

Julander, O., and D.E. Jeffery. 1964. Deer, elk, and cattle range relations on summer range in Utah. Trans. N. Amer. Wildl. and Natur. Resour. Conf. 29:404-414.

Klecka, W.R. 1975. Discriminant analysis. p. 434-467. In: N.H. Nie, C. H. Hull, J.G. Jenkins, K. Steinbrenner, and D.H. Bent (eds), Statistical package for the social sciences. McGraw-Hill, New York. 
Knowles, C.J. 1975. Range relationships of mule deer, elk and cattle in a rest-rotation grazing system during summer and fall. M.S. thesis. Montana State Univ., Bozeman.

Knowles, C.J., and R.B. Campbell. 1982. Distribution of elk and cattle in a rest-rotation grazing system. p. 46-60. In: J.M. Peek and P.D. Dalke (eds), Wildlife-lifestock relationships symposium: Proc. 10. Univ. of Idaho, Forestry, Wildlife and Range Exp. Sta., Moscow.

Long, A.J., and L.L. Irwin. 1982. Elk-cattle interactions in the Bighorn Mountains, Wyoming. p. 553-564. In: J.M. Peek and P.D. Dalke (eds), Wildlife-livestock relationships symposium: Proc. 10. Univ. of Idaho, Forestry, Wildlife and Range Exp. Sta., Moscow.

Longhurst, W.M., R.E. Hafenfeld, and G.E. Connolly. 1982. Deer-livestock interrelationships in the western states. p. 409-420. In: J.M. Peek and P.D. Dalke (eds), Wildlife-livestock relationships symposium: Proc. 10. Univ. of Idaho, Forestry, Wildlife and Range Exp. Sta., Moscow.

Mackie, R.J. 1970. Range ecology and relations of mule deer, elk, and cattle in the Missouri River Breaks, Montana. Wildl. Monogr. 20.

McIntosh, B.J., and P.R. Krausman. 1982. Elk and mule deer distributions after a cattle introduction in northern Arizona. p. 545-552. In: J.M. Peek and P.D. Dalke (eds), Wildlife-livestock relationships symposium: Proc. 10. Univ. of Idaho, Forestry, Wildlife and Range Exp. Sta., Moscow .

Nelson, J.R. 1982. Relationships of elk and other large herbivores. p. 415-422. In: J.W. Thomas and D.E. Toweill (eds), Elk of North America ecology and management. Stackpole Books, Harrisburg, $\mathrm{Pa}$.

Nelson, J.R., and D.G. Burnell. 1976. Elk-cattle competition in central Washington. p. 71-83. In: Range multiple use management. Univ. of Idaho, Moscow.
Reynolds, H.G. 1966. Use of a ponderosa pine forest in Arizona by deer, elk and cattle. U.S. Forest Serv. Res. Note RM-63. Rocky Mountain Forest and Range Experiment Station, Fort Collins, Colo.

Sivinski, R.C. 1979. A multivariate analysis of summer habitat partitioning between elk (Cervus elaphus) and mule deer (Odocoileus hemionus) in Bandelier National Monument, New Mexico. M.S. Thesis, New Mexico State Univ., Las Cruces.

Skovlin, J.M., P.J. Edgerton, and R.W. Harris. 1968. The influence of cattle management on deer and elk. Trans. $\mathbf{N}$ Amer. Wildl. and Natur. Resour. Conf. 33:169-181.

Sokal, R.R., and F.J. Rohlf. 1969. Biometry. W.H. Freeman and Co., Publishers, San Francisco.

Strickler, G.S. 1959. Use of the densiometer to estimate density of forest canopy on permanent sample plots. Res. note PNW-180. U.S. Forest Serv. Pacific Northwest Forest and Range Exp. Sta. Portland, Ore.

Strong, C.W. 1966. An improved method of obtaining density from linetransect data. Ecology 47:311-313.

Urness, P.J. 1982. Livestock as tools for managing big game winter range in the intermountain west. p. 20-31. In. J.M. Peek and P.D. and P.D. Dalke (eds), Wildlife-livestock relationships symposium: Proc. 10. Univ. of Idaho, Forest, Wildlife, and Range Exp. Sta., Moscow.

Ward, A.L., J.J. Cupal, A.L. Lea, C.A. Oakley, and R.W. Weeks. 1973. Elk behavior in relation to cattle grazing, forest recreation, and traffic. Trans. N. Amer. Wildl. and Natur. Resour. Conf. 38:327-337. 